\title{
Geospatial Analysis of Land Use/Land Cover Dynamics on Lake Abaya-Chamo Wetland in Southern Rift-Valley of Ethiopia
}

Tariku Zekarias ( $\square$ tarezekarias@gmail.com )

Arba Minch University https://orcid.org/0000-0003-4468-6924

Vanum Govindu

Arba Minch University

Yechale Kebede

Arba Minch University

Abren Gelaw

Arba Minch University

\section{Research}

Keywords: land use/land cover, dynamics, magnitude, NDWI, multispectral, Lake Abaya-Chamo wetland.

Posted Date: May 4th, 2021

DOl: https://doi.org/10.21203/rs.3.rs-407287/v1

License: (c) This work is licensed under a Creative Commons Attribution 4.0 International License. Read Full License 


\title{
Geospatial Analysis of Land Use/Land Cover Dynamics on Lake Abaya-Chamo Wetland in Southern Rift-Valley of Ethiopia
}

\author{
Tariku Zekarias $^{\mathrm{a}}$, Vanum Govindu ${ }^{\mathrm{b}}$, Yechale Kebede ${ }^{\mathrm{c}}$, Abren Gelaw ${ }^{\mathrm{d}}$ \\ a Department of Geography and Environmental Studies, Arba Minch University, POBox21, Arba \\ Minch, Ethiopia, phone: +251-913682300;Email: tarezekarias@gmail.com \\ ${ }^{\mathrm{b}}$ Department of Geography and Environmental Studies, Arba Minch University, POBox21,Arba \\ Minch, Ethiopia, phone +251-98541-4821, gisgovindu@gmail.com \\ ${ }^{\mathrm{c}}$ Department of Geography and Environmental Studies, Arba Minch University, POBox21,Arba \\ Minch, Ethiopia, phone:+251911390405E-mail: kebyechenvi@gmail.com \\ ${ }^{\mathrm{d}}$ Department of Geography and Environmental Studies, Arba Minch University, P.O.Box 21, Arba \\ Minch, Ethiopia, +251913623251, abren_mekon@yahoo.com
}

\begin{abstract}
Wetlands worldwide and in Ethiopia have long been subject to severe degradation due to anthropogenic factors. This study was aimed at analyzing the impact of land use/cover dynamics on Lake Abaya-Chamo wetland in 1990 - 2019. Data were acquired via Landsat TM of 1990, ETM+ of 2000, and OLI of 2010 and 2019 images plus using interview. Unsupervised and supervised classifications (via ERDAS14 and ArcGIS10.5) were applied to detect land use/cover classes. Normalized difference vegetation index, normalized difference water index, change matrix model and Kappa coefficients were used for analysis of the land use/cover dynamics in the lakewetland. It was found that forest; water, shrub land, agricultural land, settlement and swamp area were the main land use/cover classes. While 'settlement' and 'water body' of the lake-wetland increased at progressively increasing magnitudes of changes in three periods within 1990 - 2019, 'shrub land' and 'swamp' declined at progressively increasing magnitudes of loss in the same periods. The NDWI result revealed that 'swamp' area shrank by $48.9 \%$ (2,991 ha) due to siltation-led expansion of the lake-water in three decades. Siltation, rapid population growth-led expansion of settlement and irrigation-based farming were the main drivers of the land use/cover dynamics and degradation of the lake-wetland. Thus, consistent mapping and integrated actions should be taken to curb the threats on the sustainability of the lake-wetland in Southern Ethiopia.
\end{abstract}

Keywords: land use/land cover, dynamics, magnitude, NDWI, multispectral, Lake Abaya-Chamo wetland.

\section{Introduction}

Land Use/Land Cover (LULC) changes affect aquatic and inland ecosystems including wetlands across the globe. Technically, the concept of 'land use' is different from that of 'land cover'. 'Land use' is the purpose for which land is exploited by people; whereas, 'land cover' is the biophysical or inherent state of land above the lithosphere (Lambin et al., 2003). On the other hand, a 'wetland,' roughly upon the Ramsar Convention, is a natural or manmade swamp, 'fen or peatland' ... having soft, spongy soil/land saturated with draining or stagnant, fresh, brackish or salty water including marine with a depth (at low tide) of less than 6 meter (RCS, 2016). Inland (natural) wetlands are endowed with diverse species of flora usually dominated by 
dense growth of annual and perennial grasses, and herbaceous plants (in some cases, mixed with trees of variable densities) as well as with various species of fauna and microorganisms (Schuyt, 2005). Inland wetlands, being formed often on flat to plain landscapes, depressions (surrounded by uplands), banks and deltas of rivers (Ballanti et al., 2017), along margins of lakes, and where clayey/sticky soils are dominant, have vital economic and environmental values (Clarkson et al., 2014; CBD, 2015). Well managed inland wetlands provide myriads of benefits (services) with an estimated value of about US $\$ 44,000$ per/ha/year (TEEB, 2013).

Wetland ecosystems provide numerous services, which range from provisioning (fish, rice production, animal fodder and fossil fuels) through supportive (e.g. habitat, breeding ground of birds and crop farming) and regulatory (carbon sink, climate control and regulate hydrological cycle) to cultural (e.g. recreation and aesthetic) services (MEA, 2005; Dise, 2009; Erwin, 2009; Davidson, 2014; Clarkson et al., 2014; CBD, 2015). Huge proportion of the wetlands (marine and inland) in the world undergo complete and/or partial degradation or loss in response to the impact of natural and human factors (Schuyt, 2005; Zedler and Kercher, 2005). Climate change, sea-level rise, sediment load into wetlands, volcanism, earthquake and drought are among the main natural causes of degradation of wetlands (Morris et al., 2002; Parry et al., 2007; Ballanti et al., 2017; Galatowitsch, 2018). But the world experienced loss of about 50\% (Clarkson et al., 2014) to $64 \%$ (CBD, 2015) of the total wetlands due to largely anthropogenic factors-induced LULC dynamics, underlain by rapid population growth (CBD, 2015). Expansion of farming, urban built-up area and infrastructures, air and water pollution, runoff-induced increasing fertilizers, eutrophication, invasive exotic plant species, diversion of wetland tributaries, construction of dams and irrigation canals, and intensive exploitation of resources are among the major manmade driving forces of LULC changes and degradation/loss of wetlands worldwide (Zedler and Kercher, 2005; UNEP, 2012; CBD, 2015; Giweta and Worku, 2018; Galatowitsch, 2018).

Studies reveal that most of the riverine and lacustrine wetlands of Ethiopia have been critically threatened due to the impact of LULC changes (Feoli and Zerihun, 2000; Giweta and Worku, 2018). Numerous studies were made about various issues of wetlands in different parts of Ethiopia. Investigations about the threats and opportunities (Zinabu, 2002; Teklu and Kassahun, 2017) and hydrogeochemical and water level changes (Alemayehu et al., 2006) of Rift-Valley lake-wetlands, sustainable management (Wood and Dixon, 2002) and wetland ecosystem dynamics (Legesse, 2007) in Illubabor Zone, status of natural lakes of Ethiopia (Tenalem, 2009), water level and siltation problem of Abaya lake (Schütt et al., 2002), ecology and wetland vegetation composition (Unbushe, 2013) and limnological changes (Teffera et al., 2017) of lake Abaya-Chamo wetland, ecosystem services of Tana lake-wetland in Northwestern Ethiopia (Wondie, 2018), and reversing wetland degradation in Ethiopia (Giweta and Worku, 2018) were among the main wetland-related studies in Ethiopia. 
Most of these studies were conducted not via GIS and remote sensing-based geospatial analyses of the dynamics of the wetlands in the respective areas of Ethiopia overtime largely due to the views and thematic-area interests of the studies. It is ambiguous to understand the accurate spatiotemporal magnitudes of LULC (e.g. forest, water, swamp) changes (gains/losses) of wetlands from results of studies made without the application of GIS and remote sensing (satellite images) techniques (Lillesand et al., 2004; Ballanti et al., 2017).

Several studies have been conducted about the causes of LULC dynamics and degradation of wetlands in Ethiopia (Wood and Dixon, 2002; Tenalem, 2009; Simane et al., 2013; Teklu and Kassahun, 2017; Wondie, 2018; Giweta and Worku, 2018). Persistently high population growth led conversion of wetlands to croplands (Simane et al., 2013) and urban (built-up) areas, open access to and overuse of common (natural) resources (use of wetland trees for timber and fuel, intensive and inefficient water use for irrigation and overgrazing) (Tenalem, 2009; Teklu and Kassahun, 2017), lack of regulations about use and abuse of resources, absence of service costs (i.e. the free riders/tragedy of the commons' scenario), draining wetlands, dam construction, intensification of farming, infrastructure expansion and diversion of water flowing to wetlands (Zinabu, 2002; Wood and Dixon, 2002; Wondie, 2018), poor catchment management, sedimentation, eutrophication and pollution by chemical farm-inputs (Giweta and Worku, 2018) were among the major drivers of LULC dynamics and wetland degradation in different parts of Ethiopia. But all the causes (shown above) cannot be equally significant in inducing LULC changes and threatening wetlands everywhere as the drivers and their impacts vary in space and time depending on variations in circumstances across the different specific areas of the country (Giweta and Worku, 2018).

GIS and satellite image-based studies about the dynamics and threats of wetlands in Ethiopia were limited. Dynamics of Dawa Chefa Wetland in North central part (Hussien, 2014), characterizing wetlands and their dynamics in Central Highlands (Dubeau, 2016), and the impact of LULC change on the landscape of AbayaChamo basin (Wolde-Yohannes et al., 2018) were among the few GIS and remote sensing-based studies made in Ethiopia in the recent past. Studies made through integrated application of different data acquisitions (GIS and satellite images, ground survey and interview) and analyses (NDVI, NDWI) techniques for addressing the dynamics and threats of wetlands were rare in and around lake Abaya-Chamo wetland (Southern Rift-Valley of Ethiopia) where this study is conducted. Remote sensing-based mapping and analyses of the dynamics of biophysical status of wetland (upon multispectral Landsat images) is useful to develop bases for detecting and monitoring changes (degradation) of the wetland, and to respond for its restoration (Baker et al., 2007; Klemas, 2011; Ballanti et al., 2017). This is so because, GIS and remote sensing techniques, by providing synoptic coverage and repeatability of spatial information, enable to get accurate results about wetland dynamics and are more cost-effective for monitoring the changes overtime (Ballanti et al., 2017). This study was aimed to: (1) quantify the magnitude and rate of LULC dynamics of Lake Abaya-Chamo wetland within 
1990 - 2019; (2) explain the trends of LULC changes in three decades; (3) analyze the driving forces and impacts of the LULC dynamics on the degradation/sustenance of the lake-wetland.

\section{Research Methods}

\section{Study Area}

Abaya-Chamo lake-wetland is located in $5^{\circ} 43^{\prime} 19^{\prime \prime} \mathrm{N}-6^{\circ} 38^{\prime} 51^{\prime \prime} \mathrm{N}$ latitude and $37^{\circ} 21^{\prime} 55^{\prime \prime} \mathrm{E}-38^{\circ} 15^{\prime} 05^{\prime \prime} \mathrm{E}$ longitude (Figure 2.1). In Figure 2.1, the large Northeastern water body is Abaya Lake and the smaller Southwestern one is Chamo lake. The area of Abaya-Chamo lake-wetland is 242,615 ha (Figure 2.1). Abaya and Chamo lakes, being Rift-Valley lakes in Southern Ethiopia, lie on a graven (depression) created by faulting due to divergent movement along the boundary of the Africa plate (westward) and the Somali plate (eastward). The Western part of the lake-wetland is largely plain, where some dome-shape and conical volcanic hills, and elevated spurs are observed.

Climatically, Abaya-Chamo wetland, based on data of 1987 - 2018 Mean annual temperature, was about $24{ }^{0} \mathrm{C}$; and, the mean monthly temperature of the area is the highest in march $\left(26{ }^{\circ} \mathrm{C}\right)$ and the lowest in July $\left(23^{\circ} \mathrm{C}\right)$, November $\left(23.1{ }^{0} \mathrm{C}\right)$ and December $\left(23.1{ }^{0} \mathrm{C}\right)$ (NMA, 2019). The wetland receives a somewhat low rainfall amount where the mean total annual $(1982$ - 2018) was $870.9 \mathrm{~mm}$. The study area has two rainfall seasons: that is, spring (March, April and May) with total rainfall of $362.9 \mathrm{~mm}$ is the main rainy season. In spring, rainfall, averaged for 37 years (1982 - 2018), is the highest in April (153.7 mm). Autumn (September, October and November) with total rainfall amount of $265.6 \mathrm{~mm}$ is the second rainy season where it peaks in October (115 mm) (NMA, 2019). 


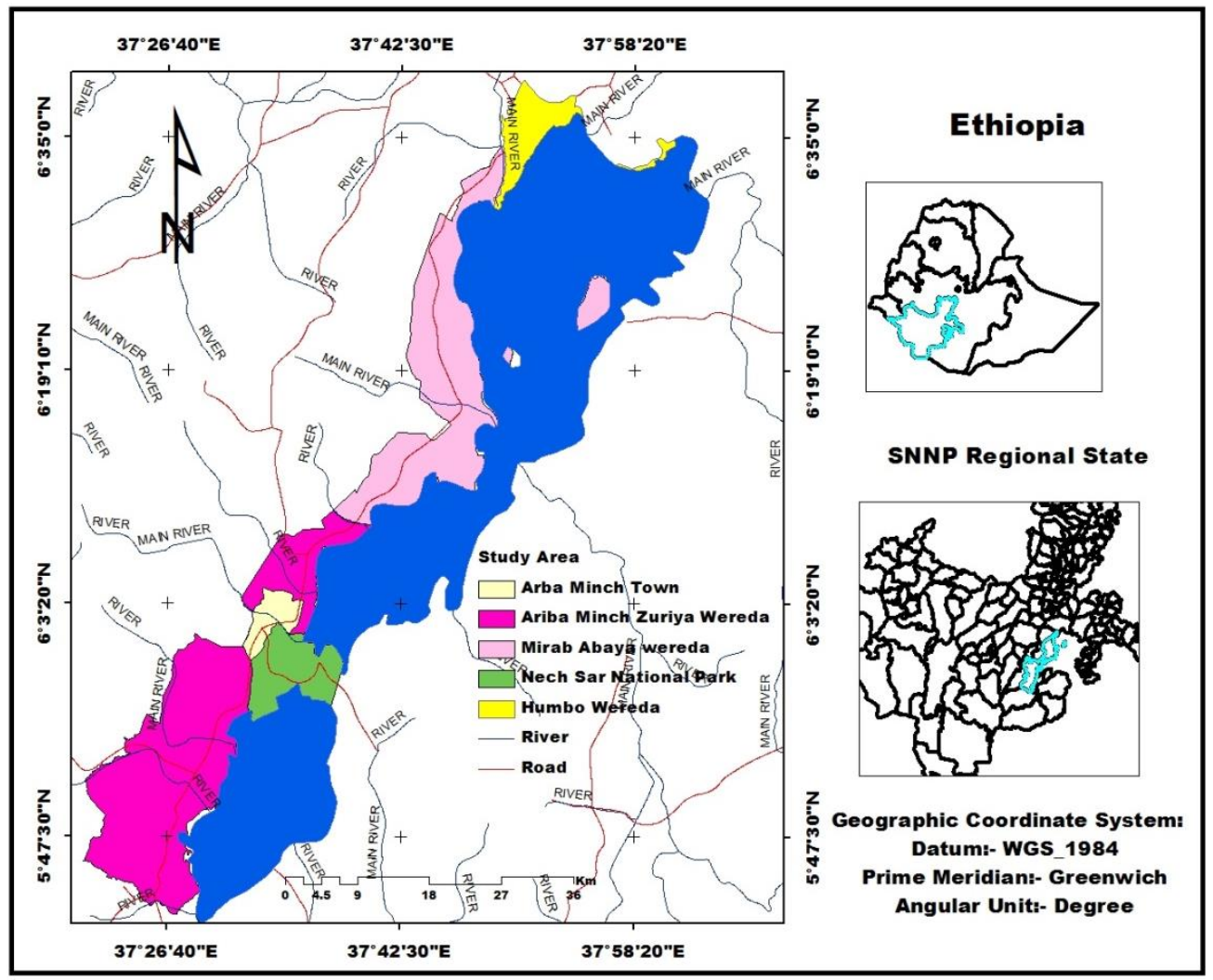

Figure 2.1 Lake Abaya-Chamo Wetland and Its Surrounding Areas (Source: Own Design via ArcGIS, 2021)

Abaya-Chamo lake-wetland provides multiple ecological and economic benefits to people in the surrounding area. The wetland vegetation, being a vital nesting site and feeding source for hundreds of birds and hippopotamus, supports wildlife and serves as a spawning-area for crocodiles (Unbushe, 2013). Rich bird fauna, sport fishing for Tilapia, Nile Perch and Tiger Fish, the 'Azo-gebeya'/'Crocodile Market' (where crocs are not exchanged rather crowds of crocs are visited), the 'Forty-Springs' (from which name of 'Arba-Minch' Town was coined) provide special attraction to tourists. Crocodile Ranching/Farming is important income source via tourism and the export of skin of crocs (Legesse, 2007). The lakes also harbor large population of common hippopotamus (Hippopotamus amphibius) and several rare bird species including migratory ones.

Lake Abaya-Chamo wetland revealed rapid change in land uses/land covers due to fast population growthinduced expansion of cultivated land and settlement at the cost forest and shrub land (Bekele, 2001). Crop farming and livestock rearing are important activities in the area surrounding the lakes. Extensive area to the West of Lake Abaya was cleared in the 1960s and 1970s for expansion of large-scale farms for producing cotton, banana and other crops (Gelaw, 2019). State farms like Bilate, Arba-Minch and Sile (recently given for private investors) are examples of intensive farming in the plain area adjacent to the lakes. 
Agroforestry is the main activity in the alluvial plain of the western shores of the lakes, where it is practiced using rain-fed and irrigation. Fruits (e.g. banana, mango, avocado, papaya, tomato,), cereals (e.g. maize), vegetables (e.g. cabbage, pepper), tuber and root crops (casava, onion, carrot) and cotton are cultivated on the fertile soils adjacent to the wetland (Gelaw, 2007; Gelaw, 2019). Wetlands, forest, woodland and bush-lands have changed to settlement and cropland (Kebede, 2012). These wetlands present a rich biodiversity in western shores of the lake Abaya-Chamo wetland even if it has been extremely impacted by anthropogenic pressure.

\section{Research Methods}

\section{Research Design}

This study, being viewed via the pragmatic lens, was conducted based on the mixed-methods approach. That is, data acquisition and analyses were carried out using a mixture of methods from both the quantitative and qualitative approaches (Creswell, 2009). Kappa coefficient, Normalized Difference Vegetation Index (NDVI) and Normalized Difference Water Index (NDWI) were used for statistical based inferences about the LULC dynamics and the degradation of Lake Abaya-Chamo wetland. Methods of the qualitative approaches such as interview and observation were used to check, confirm and strengthen the findings of the quantitative approach. The concurrent embedded model was used to mix the quantitative and qualitative approaches (Creswell, 2009). Cross-sectional survey design was used to acquire and analyze data using both the methods of quantitative and qualitative approaches simultaneously (in parallel).

\section{Acquisition and Processing of Satellite Images}

Landsat TM of 1990, ETM+ of 2000, and OLI of 2010 and 2019 of Lake Abaya-Chamo wetland, having spatial resolution of $30 \mathrm{~m}$ were downloaded from the website (https://earthexplorer.usgs.gov/) of the US Geological Survey (USGS) (Table 1). Landsat images captured during January and February were preferred since these dates enable to acquire satellite images free of the impact of cloud cover and to avoid the effect of seasonal variation on the classification of LULC classes. Digital Elevation Model (DEM) with $30 \mathrm{~m}$ resolution (upon Aster imagery) was also used to acquire spatial data. Ancillary data were also utilized during analysis. All data (images) were projected to the Universal Transverse Mercator (UTM) projection system, zone 37N and datum of World Geodetic System-84 (WGS84) to ensure consistency between datasets during analyses. 
Table 1. Sensor Type, Resolution, Acquisition Date and Source of Satellite Images used for the Study

\begin{tabular}{lcccc}
\hline \multicolumn{1}{c}{ Sensor Type } & Resolution & Path/Row & Acquisition Date & Source \\
\hline Landsat-5 TM & $30 \mathrm{~m}$ & $169 / 56,169 / 55$ & Jan 12, 1990 & http://earthexplore.usgs.gov \\
Landsat-7 ETM+ & $30 \mathrm{~m}$ & $169 / 56,169 / 55$ & Jan 27, 2000 & http://earthexplore.usgs.gov \\
Landsat-8 OLI & $30 \mathrm{~m}$ & $169 / 56,169 / 55$ & Mar 05, 2010 & http://earthexplore.usgs.gov \\
Landsat-8 OLI & $30 \mathrm{~m}$ & $169 / 56,169 / 55$ & Mar 10, 2019 & http://earthexplore.usgs.gov \\
\hline
\end{tabular}

Source: Own Summary, 2020

The imageries were checked against any defects such as striping. All image scenes were subjected to image processing using ENVI software (version 5.3), and each was clipped using the base-map of lake Abaya-Chamo wetland. Geometric and radiometric corrections were made for the images of the four periods (Table 1). The two scenes (i.e. the one that fall within path 169 and row 56, and the other that fall in path 169 and row 55) of each data set were mosaicked using linear contrast stretching and histogram equalization technique to create a single image covering the whole study area for each period.

\section{Image Classification and Accuracy Assessment}

Unsupervised and supervised classification techniques were used to identify about six LULC classes of Lake Abaya-Chamo wetland. Unsupervised procedure was used to classify the LULC classes of the lake-wetland in 1990, 2000, 2010 and 2019. Unsupervised classification technique is the Iterative Self-Organizing Data Analysis Technique Algorithm (ISODATA) that depends upon the natural groupings of the spectral properties of the pixels, which are usually selected by the remote sensing software without any influence from the user (Lellisand et al., 2004; Govender et al., 2007). About six LULC classes were produced (via unsupervised classification) by merging unknown distribution of pixel values in the image data using ERDAS IMAGINE 2014 before the field work. The six LULC classes are agricultural land, forest, settlement, shrubland, water-body and swamp.

Landsat TM of 1990, ETM+ of 2000, and OLI of 2010 and 2019 were also classified using supervised classification (maximum likelihood technique) separately to identify LULC classes of the study area. This method assumes the normal distribution of DN values, allowing the function to determine the probability of a pixel belonging to a specific feature class and assign each pixel to the highest probability class (Lillesand et al., 2004). The classifications were repeated numerous times by adding more training sites so as to come up with satisfactory results. Supervised classification was chosen to compare the outputs with results of the unsupervised classification; this was particularly vital for this study because it identifies and locates LULC types, which are known priori through a combination of interpretation of aerial photography, survey analysis and fieldwork. 
In the accuracy assessment, confusion matrices and Kappa coefficient of agreement were calculated for each classification map. Estimation of Kappa coefficients yields statistics, which are measures of agreement or accuracy between the remote sensing-derived classification map and reference data (as shown by the major diagonal) and the chance agreement, which is indicated by the row and column totals (referred to as marginal) (Jensen, 2009). The classification results were compared with the ground truth (data) to confirm accuracy of the classification process. It is a way of assuring how many ground truth pixels were classified correctly, and how much errors were propagated during data acquisition, analysis and conversion (Edwards et al., 1998). In this study, the accuracy assessment was done for the recent satellite image (2019) for which the ground truth data were likely to correspond. An error matrix is square array of numbers set out in rows and columns which express the number of sample units (i.e. pixels, cluster of pixels or polygons) assigned to a particular category relative to the actual category as verified on grounds. The $\check{\mathrm{K}}$ ("KHAT") statistic is a measure of the difference between the actual agreement between reference data and an automated classifier and the chance agreement between the reference data and a random classifier (Jensen, 1996). Conceptually, Ḱ can be defined as:

$$
\dot{\mathrm{K}}=\frac{\text { observed accuracy }- \text { chance agreement }}{1-\text { Chance agreement }}
$$

In reality, the value of $\breve{\mathrm{K}}$ usually ranges between 0 and 1 . Kappa coefficient of is calculated as follows:

$$
\widehat{K}=\frac{N \sum_{1}^{k} x_{i i}-\sum_{1}^{k}\left(x_{i+} \times x_{+i}\right)}{N^{2}-\sum_{1}^{k}\left(x_{i+} \times x_{+i}\right)}
$$

Where: $N$ is the total number of observations in the entire error matrix, $k$ is the total number of classes or categories, $x_{i i}$ refers to the number of observations correctly classified for a particular category, and $x_{i+}$ and $x+i$ refer to the marginal totals for row $i$ and column $i$ associated with the category.

\section{Collection of Field Data and Verification}

Reference data were collected for training and validation of each LULC type of Abaya-Chamo lake-wetland for each satellite image in each period. Geographic locations of ground truth LULC classes, used to calibrate the classification procedure, were identified using high spatial resolution imagery made freely available through Google Earth Pro. About 120 reference samples were derived from the LULC of the lake-wetland in 2019 and via the support of Spot map of 2019. Reference data for 2019 were collected directly from the field between September 2018 to February 2019 using handheld GPS. About 80, 86, 100 and 100 GCP samples were collected for 1990, 2000, 2010 and 2019, respectively, which were used for accuracy assessment.

Verification of the mapped lake-wetland was done through field visits, comparison with features on Google Earth and the DEM, and the use of prior knowledge of features present in the study area. The ground-truth 
points were randomly chosen. Ground-truthiness of the mapped features was necessary for the verification and accuracy assessment of the features.

\section{Techniques of Data Analysis}

LULC changes of Lake Abaya-Chamo wetland were analyzed using GIS and remote sensing techniques. Determination of appropriate classes was done based on level 'I' of the LULC classification and six classes were identified (Table 2). Computer aided interpretation of images was conducted using environmental resources data analysis system (ERDAS) Imagine 2014, ArcGIS 10.5, GPS (Garmin 5.1)-based data and environment for visualizing images (ENVI) 5.0 software, which were used for satellite image processing, classification of LULC, accuracy assessment and analysis of the wetland dynamics. Microsoft excel was also used for analysis.

Arc Map GIS 10.5 raster calculator was used to perform the change detection analysis. Change detection analysis was applied on results of the unsupervised and supervised classification about the six LULC classes of Abaya-Chamo lake-wetland for periods 1990 -2000, 2000 -2010, 2010 - 2019 and 1990 - 2019. The magnitude of area change of each LULC class in each period was calculated as follow:

$$
M=\left(A_{2}-A_{1}\right) / A_{1} * 100
$$

Where: $M$ is magnitude of area change of a LULC class in a period, $A_{l}$ is area (ha) of the LULC class in the initial or earlier year, and $A_{2}$ is area (ha) of the same LULC class in the recent year. The annual rate of change of each LULC class for each period was computed as:

$$
R=\left(A_{2}-A_{1}\right) / t * 100
$$

Where: $R$ is annual 'Rate' of area change (in ha and \%), $A_{l}$ is area (ha) of a LULC class in the initial year, $A_{2}$ is area (ha) of the LULC class in the recent year, and ' $t$ ' is the time-interval between the initial and recent years.

Change matrix model (the raster calculator) was used to compute the area change from one LULC class to another type between the periods accounted in the study. The magnitude of change for each period was statistically tested using the Wilcoxon Signed-ranks test. The Wilcoxon Signed-ranks test is a non-parametric statistical test used to assess the difference between two conditions where the samples, in this case change of LULC class, are correlated. The data sets can be compared repeatedly over consistent periods (between initial and recent years).

Normalized Difference Water Index (NDWI): was used to extract water (wet) area of the study site. Combination of band 2 (green) and band 4 (near-infrared) was used for Landsat 5 TM and Landsat 7 ETM+ 
images. Band 3 (green) and band 5 (near-infrared) were combined for Landsat 8 OLI imageries. Thus, the NDWI, useful to identify open-water features (wet-area), was computed as (McFeeters, 1996):

$$
N D W I=\frac{\text { Green band }-N I R \text { band }}{\text { Green band }+N I R \text { band }}
$$

The NDWI ranges between -1 and +1 , where increasing positive values indicate increasing water presence and negative values indicate dry surface (decreasing wet/water). The NDWI indices, which indicate moisture content, are used as wet-land/swamp area proxies. Where a wetland is covered by hydric-soils or is dry the NDWI values are expected to be low (lower than -0.3) due to the absence of moisture. Fluctuations in the NDWI values of a wetland indicate variable frequency of occurrence of its water. NDWI values above 0 represent water presence.

Normalized Difference Vegetation Index (NDVI): NDVI was used to assess the presence of live green vegetation in Abaya-Chamo lake-wetland. The NDVI was computed as follow:

$$
N D V I=\frac{\mathrm{NIR}-\mathrm{REd}}{\mathrm{NIR}+\mathrm{RED}}
$$

NDVI values range from -1 to 1 . The higher the NDVI, the higher the fraction of live green vegetation present in the scene. Landsat band $4(0.76-0.90 \mathrm{~mm})$ measures the reflectance in NIR region and band $3(0.63-0.69 \mathrm{~mm})$ measures the reflectance in Red region. NDVI for the Landsat 8 image was computed using bands 4 and 5 for Red and NIR, respectively.

Table 2. Contextual Description of the LULC Categories/Classes of Abaya-Chamo Lake-Wetland

\begin{tabular}{|l|l|}
\hline Category & Description/Definition \\
\hline Agriculture & $\begin{array}{l}\text { Farmland used for growing cereals, tuber and root crops, agroforestry practice and horticulture } \\
\text { including currently uncultivated (arable) land and fallowed plots. }\end{array}$ \\
\hline Shrubland & $\begin{array}{l}\text { Area covered with more of short, hard woody stem trees (bushes), limited herbaceous plants } \\
\text { (shrubs) and isolated trees which often are mixed with undergrowth of grasses. }\end{array}$ \\
\hline Forest & Area of dense, tall trees having interlocked canopies, including woodland and riverine forests \\
\hline $\begin{array}{l}\text { Swamp/ } \\
\text { wetland }\end{array}$ & $\begin{array}{l}\text { Is spongy, soft, wet/marshy land saturated with water, adjacent to Abaya and Chamo lakes, and on } \\
\text { the banks of tributary-rivers (of the lakes) having permanent and seasonal grasses. }\end{array}$ \\
\hline $\begin{array}{l}\text { Water } \\
\text { body }\end{array}$ & $\begin{array}{l}\text { Area with temporary and permanent water cover which includes lakes, intermittent ponds and } \\
\text { other areas with shallow water cover. }\end{array}$ \\
\hline Settlement & $\begin{array}{l}\text { Consists of homesteads of rural villages and buildings of urban areas (with commercial and } \\
\text { residential purposes), camps, warehouses, roads and other infrastructures. }\end{array}$ \\
\hline
\end{tabular}

Source: Own Summary, 2020 


\section{Results and Discussion}

\section{Assessment of Accuracy of LULC Classification and Change Detection:}

Accuracy assessment was run in order to measure (statistically) the level of accuracy and degree of acceptance of analysis results of the GIS and remote sensing-based LULC classification and change detection of AbayaChamo lake-wetland, Southern Ethiopia (Table 4). Accuracy levels of all the six LULC classes upon values of both the Producer's Accuracy (PA) and User's Accuracy (UA) were approximately $80 \%$ and above except the PA of 'forest' for the period 1990 (79.03\%), 2010 (79.02\% and 2019 (78.79\%) (Table 4). The low accuracy level of forest in the three periods under study could be perhaps due to proximity in the spectral/reflectance value of 'forest' to that of 'agroforestry' (agriculture) of mango trees, which creates ambiguity during image classification. Anyway, results of the PA and UA indicate that all the classified LULC classes of 1990, 2000, 2010 and 2019 satisfy the recommended accuracy level (above $80 \%$ ); that is, there are strong agreements between the classified LULC classes and the GCP data.

Table4. Producer's Accuracy (PA) and User's Accuracy (UA) of LULC Maps of 1990, 2000, 2010 and 2019

\begin{tabular}{lcccccccc}
\hline \multirow{2}{*}{ LULC Class } & \multicolumn{2}{c}{1990} & \multicolumn{2}{c}{ 2000 } & \multicolumn{2}{c}{$\mathbf{2 0 1 0}$} & \multicolumn{2}{c}{$\mathbf{2 0 1 9}$} \\
\cline { 2 - 8 } & PA (\%) & UA (\%) & PA (\%) & UA (\%) & PA (\%) & UA (\%) & PA (\%) & UA (\%) \\
\hline Forest & 79.03 & 82.22 & 88.64 & 92.12 & 79.02 & 84.00 & 78.79 & 92.86 \\
Water & 90.00 & 82.93 & 91.60 & 88.00 & 86.40 & 86.00 & 96.80 & 93.75 \\
Settlement & 91.06 & 80.00 & 92.80 & 86.01 & 86.02 & 84.05 & 92.50 & 88.72 \\
Shrub-land & 79.60 & 81.90 & 81.02 & 87.07 & 82.01 & 88.04 & 83.33 & 83.33 \\
Agriculture & 84.05 & 91.07 & 89.07 & 79.80 & 86.60 & 85.01 & 86.05 & 88.10 \\
Swamp & 86.03 & 87.50 & 87.40 & 88.05 & 89.03 & 86.00 & 92.10 & 100.00 \\
\hline Kappa statistics & \multicolumn{2}{c}{88.90} & 90.21 & 91.20 & 97.92 \\
Kappa coefficient & \multicolumn{2}{c}{0.887} & 0.890 & 0.884 & 0.968 \\
\hline
\end{tabular}

Source: Own Summary upon Result of the GIS Analysis, 2020

The Kappa statistics for periods 1990, 2000, 2010 and 2019 were 88.9\%, $90.2 \%, 91.2 \%$ and $97.9 \%$, respectively, and Kappa coefficients of the respective periods were 0.887, 0.890, 0.884 and 0.968 (Table 4). Kappa coefficient is a measure of agreement/accuracy between the reference data and the values of LULC classes in the classified image; its coefficients range from +1 to -1 . Kappa coefficient of $0.0-0.20,0.21-0.40$, $0.41-0.60,0.61-0.80$ and $0.81-1.0$, respectively, indicate slight, fair, moderate, substantial and strong/perfect agreement; and a coefficient of < 0 reflect no agreement (Manonmani \& Suganya, 2010). The 
high Kappa coefficients reveal that the GIS-based classifications of the 1990, 2000, 2010 and 2019 LULC classes were accurate as they showed strong agreement with the GCP data. This level of agreement/accuracy is acceptable for classification, detection and prediction of LULC changes.

\section{Magnitude, Rate and Trend of LULC Dynamics in Abaya-Chamo Lake-Wetland}

Abaya-Chamo lake-wetland experienced dynamics among the different LULC classes within 1990 - 2019. Forest, water-body, settlement, shrub-land, agricultural land and wetland are the main LULC classes of the lakewetland based on the GIS-based image classification. As is illustrated in Table 3, settlement area in the Western coast of Abaya-Chamo lake-wetland revealed a continuously increasing trend in the three periods accounted in by the study, that is, where it has expanded by $47.1 \%$ (5,147 ha), $27.2 \%$ (4,373 ha) and $55.3 \%(11,298 \mathrm{ha})$ in the periods 1990 - 2000, 2000 - 2010 and 2010 - 2019, respectively. Similarly, 'water body' with magnitude of expansion of $0.4 \%$ (599 ha), $0.7 \%$ (967 ha) and $1.1 \%$ (1,443 ha) in the periods $1990-2000,2000-2010$ and 2010 - 2019, respectively, exhibited a consistently increasing trend in the three decades studied. However, the increasing trend of 'water body' was different from that of 'settlement' in that 'water body' of the lake-wetland had been increasing with consistently increasing magnitude of change as one moves from the earliest period (1990-2000) through the next (2000 -2010) to the latest period (2010- 2019) accounted in by the study (Table 3).

Table3. Area and percentage Change (ha) between LULC Classes of Lake Abaya-Chamo Wetland between 1990- 2019

\begin{tabular}{|c|c|c|c|c|c|c|c|c|c|c|c|c|}
\hline \multirow{2}{*}{$\begin{array}{l}\text { LULC } \\
\text { Class }\end{array}$} & \multirow{2}{*}{$\begin{array}{l}1990 \\
\text { (ha) }\end{array}$} & \multirow{2}{*}{$\begin{array}{l}2000 \\
\text { (ha) }\end{array}$} & \multirow{2}{*}{$\begin{array}{l}2010 \\
\text { (ha) }\end{array}$} & \multirow{2}{*}{$\begin{array}{c}2019 \\
\text { (ha) }\end{array}$} & \multicolumn{2}{|c|}{$1990-2000$} & \multicolumn{2}{|c|}{$2000-2010$} & \multicolumn{2}{|c|}{$2010-2019$} & \multicolumn{2}{|c|}{$1990-2019$} \\
\hline & & & & & A (ha) & $\%$ & A (ha) & $\%$ & A (ha) & $\%$ & A (ha) & $\%$ \\
\hline Forest & 9719 & 6301 & 12511 & 10585 & -3418 & -35.2 & 6210 & 98.6 & -1926 & -15.4 & 866 & 8.9 \\
\hline Water & 134708 & 135307 & 136274 & 137717 & 599 & 0.4 & 967 & 0.7 & 1443 & 1.1 & 3009 & 2.2 \\
\hline Settle. & 10921 & 16068 & 20441 & 31739 & 5147 & 47.1 & 4373 & 27.2 & 11298 & 55.3 & 20818 & 190.6 \\
\hline Shrubland & 50636 & 49424 & 38983 & 25869 & -1212 & -2.4 & -10441 & -21.1 & -13114 & -33.6 & -24767 & -48.9 \\
\hline Agri & 30515 & 30099 & 29857 & 33580 & -416 & -1.4 & -242 & -0.8 & 3723 & 12.5 & 3065 & 10.0 \\
\hline wetland & 6116 & 5416 & 4549 & 3125 & -700 & -11.4 & -867 & -16.0 & -1424 & -31.3 & -2991 & -48.9 \\
\hline Total & 242615 & 242615 & 242615 & 242615 & $\mathbf{0}$ & 0.0 & $\mathbf{0}$ & 0.0 & $\mathbf{0}$ & 0.0 & $\mathbf{0}$ & 0.0 \\
\hline
\end{tabular}

Source: Own Analysis via ArcGIS, 2021 (Note: Settle = Settlement. Agri = Agriculture land)

Contrary to the reality about 'settlement' and 'water' body, 'shrubland' and 'swamp' area revealed consistently declining trends in the three periods within 1990 - 2019. For instance, 'shrubland' cover with magnitude of change of $2.4 \%$ (1,212 ha), $21.1 \%$ (10,441 ha) and $33.6 \%$ (13,114 ha) in the period $1990-2000,2000-2010$ and 2010 - 2019, respectively, exhibited continuous decline in three decades. In the same way, 'swamp' area 
has continuously declined throughout 1990 - 2000, 2000 - 2010 and 2010 - 2019 where its magnitude of shrinkage in the respective periods was $11.4 \%$ (700 ha), $16 \%$ (867 ha) and 31.3\% (1,424 ha) (see Table 3 ).

On the other hand, as one moves from the period 1990 - 2000 to 2000 - 2010 and then to 2010 - 2019, forest cover and agricultural land of Abaya-Chamo lake-wetland revealed no clear trends in their patterns of change across the three decades. In fact, both 'forest' cover and 'agricultural' land experienced similar (declining) trend in the initial period $(1990$ - 2000) studied, where the magnitude of change (decline) of the respective LULC classes was $35.2 \%$ (3,418 ha) and $1.4 \%$ (416 ha). However, forest area of the lake-wetland revealed an increase by $98.6 \%(6,210 \mathrm{ha})$ while 'agricultural' land continued to decline by $0.8 \%$ (242 ha) in the next/second period (2000 - 2010) under study (Table 3). In the last period (2010 - 2019) accounted in by the study, the trend of forest cover of Lake Abaya-Chamo wetland was reversed to decline by $15.4 \%$ (1,926 ha); whereas, the agricultural land of the study site increased by $12.2 \%$ (3,723 ha) (see Table 3 ).

In the last two columns of Table 3, the overall magnitudes of change of the six LULC classes of Lake AbayaChamo wetland have been computed and displayed. Settlement, agriculture, water body and forest cover of lake Abaya-Chamo wetland with magnitudes of changes of $190 \%$ (20,818 ha), $10 \%$ (3,065 ha), $2.2 \%$ (3,009 ha) and $8.9 \%$ (866 ha), respectively, revealed net increases in three decades (1990 - 2019). Settlement and agricultural areas of the study site have been expanding at $6.4 \%$ (693.9 ha) and $0.3 \%$ (102.2 ha) per annum, respectively, in the last three decades (1990 - 2019). Similarly, the annual rates of increase of forest cover and water surface of lake Abaya-Chamo wetland in the 30-years' period were $0.3 \%$ (28.9 ha) and $0.07 \%$ (100.3 ha), respectively. On the contrary, shrubland cover of the study area experienced significant net decline by 48.9 $\%(24,767 \mathrm{ha})$ in the same period; this implies that shrubland cover of the lake-wetland has been declining at a rate of $1.6 \%$ (825.6 ha) per/year in the three decades studied. The area extent of wetland/'swamp' cover also showed a net decline by $48.9 \%$ (2,991 ha) in 1990 - 2019, where the wetland/swamp area of the study site has been shrinking at $1.6 \%$ (99.7 ha) each year in the three decades' period (Table 3).

Indices such as NDVI and NDWI were also computed for 1990, 2000, 2010 and 2019 so as to detect the 'water' and 'non-water' area dynamics of lake Abaya-Chamo wetland (Table 5 and Figure 4).

Table 5. NDVI and NDWI Thresholds of Area Classes of the Lake-Wetland for 1990, 2000, 2010 and 2019

\begin{tabular}{lcccccccc}
\hline \multirow{2}{*}{ Class } & \multicolumn{2}{c}{1990} & \multicolumn{2}{c}{ 2000 } & \multicolumn{2}{c}{ 2010 } & \multicolumn{2}{c}{ 2019 } \\
\cline { 2 - 8 } & NDVI & NDWI & NDVI & NDWI & NDVI & NDWI & NDVI & NDWI \\
\hline Water & -0.50 & -0.75 & -0.65 & 0.88 & -0.57 & 0.92 & -0.20 & 0.16 \\
\multirow{2}{*}{ Non-water } & 0.70 & 0.91 & 0.51 & -0.44 & 0.70 & -0.63 & 0.99 & -0.40 \\
\hline
\end{tabular}

Source: Own Analysis via ArcGIS, 2021 
Results of both the NDVI and NDWI (in each period) were opposite/contradicting between 'water' and 'nonwater' covers of the maps illustrating Abaya-Chamo lake-wetland. The NDVI and NDWI results revealed that there were significant changes in the 'non-water' (vegetation) and 'water' area of the study site in 1990 - 2019 (Table 5 and Figure 3). The water surface area of Abaya-Chamo lake-wetland showed an increasing trend in the three decades studied. Contrary to this, the 'non-water' (including wet/swamp) area exhibited continuous decline in the same period (1990 - 2019). Moreover, while the NDVI change revealed maximum pixels under increasing change category of the study site, the same category of change exhibited minimum pixels in the NDWI results of the change detection. In other words, results (indices) of both the NDVI and NDWI change detection analyses were accurate, and the entire study made using remote sensing technology-based analysis was also effective.

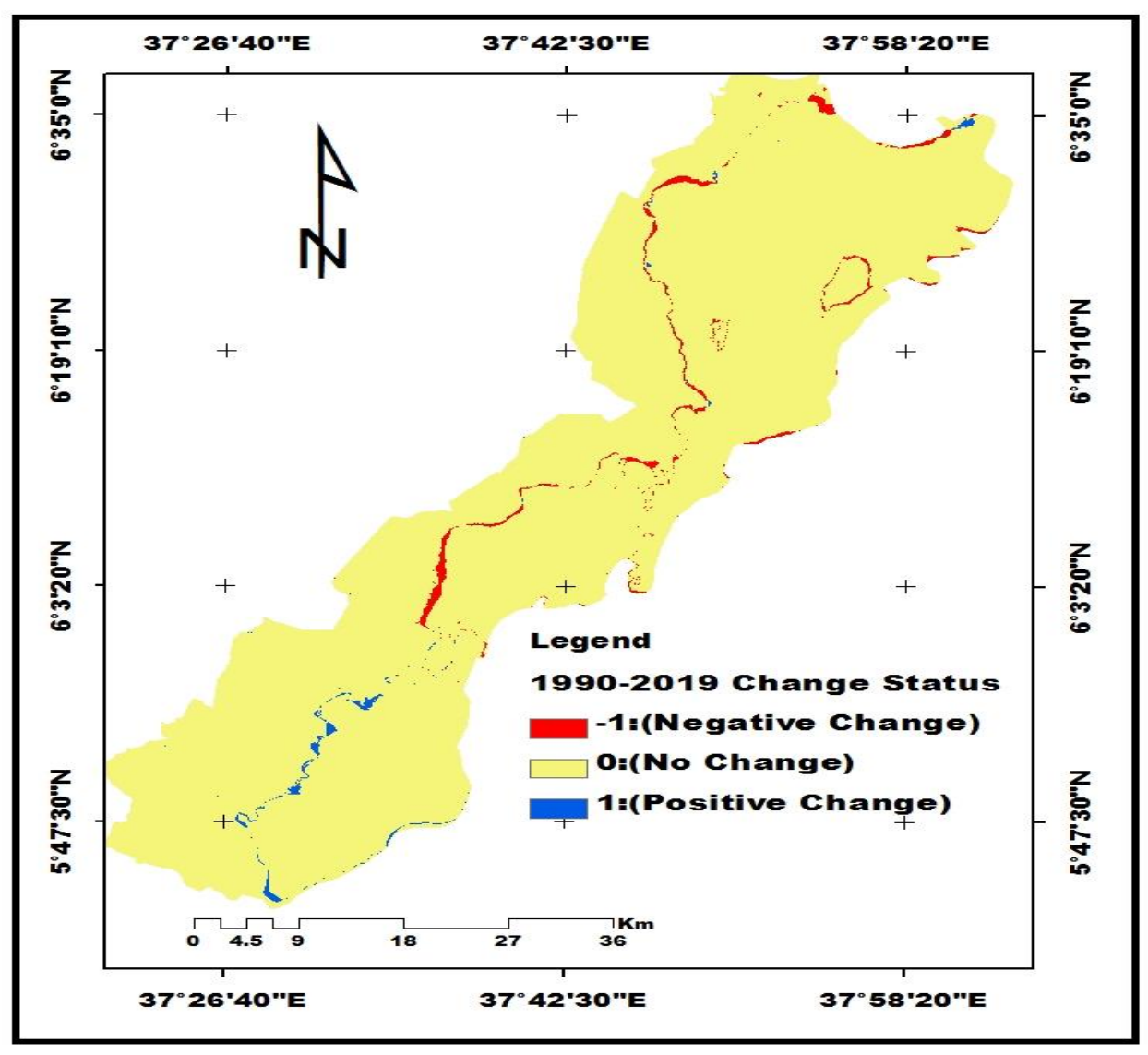

Figure 3. Map of the Dynamics of the Lake-Wetland in 1990 - 2019 (Source: Own Analysis via ArcGIS, 2021)

\section{Driving Forces and Impacts of the LULC Dynamics in Lake Abaya-Chamo Wetland}

The net increase in forest cover of lake Abaya-Chamo wetland (by $8.9 \%$ or 866 ha) in the period $1990-2019$, most likely, was a result of the expansion of agroforestry (e.g. banana, mango, avocado and papaya) practice at 
the expense of shrubland in the Western cost of the lake-wetland. In other words, the categorization of, especially, mango-forest during image classification, to a little extent, is thought to have contributed to the increase in forest cover in 1990 - 2019; that is why the accuracy level of forest cover (upon the producer's index) was the lowest for 1990 (79\%), 2010 (79\%) and 2019 (78.8\%) (See Table 4 below). The expansion of agroforestry practice is also assumed to have been among the reasons for the low magnitude of increase (by 10 $\%$ or 3,065 ha only) of agricultural land in the three decades studied; this is so because, smallholder farmers in the Western coast of the lake-wetland were indicated to have been replacing the maize-dominated cereal croplands with banana and mango-dominated agroforestry (Gelaw, 2007); that is why (despite the increasing human population in Abaya-Chamo depression/basin) agricultural land of the study site had exhibited decreasing trend by $1.4 \%$ (416 ha) in $1990-2000$ and by $0.8 \%$ (242 ha) in $2000-2010$ (Table 3). In fact, the lateral expansion of Abaya and Chamo lakes' water was also the other driving force for the decline of agricultural land; the siltation-led expansion of the lake water, according to a priest (age 58) having farmland in Lante Kebele (administrative unit) (Western cost of lake Abaya), has invaded significant share of his farmland and the landholdings of other smallholder farmers who have farm-plots proximate to the lake.

Population growth-induced expansion of settlement (by $190 \%$ or 20,818 ha) in the study area (in 1990 - 2019) has also contributed for the significant decline in shrubland cover (Table 3). An informant (age 47) also added that migrants played significant role in the reduction of shrubland area surrounding Abaya and Chamo lakes. Result of the GIS-based change detection revealed that 'shrubland' of the study site has been declining at progressively increasing magnitudes of changes in 1990 - 2019; that is, where its magnitude of decline was small ( $2.4 \%$ or $1,212 \mathrm{ha}$ ) in 1990 - 2000, medium ( $21.1 \%$ or 10,441 ha) in $2000-2010$ and the largest (33.6\% or $13,114 \mathrm{ha})$ in the latest period $(2010$ - 2019) studied (Table 3). This happened largely due to increasing conversion of 'shrubland' to cropland (since the turn of the $21^{\text {st }} \mathrm{C}$ ) by local farmers and small-scale investors who began extensive use of the salty-water of Abaya and Chamo lakes for irrigation-based cash crop production (e.g. banana, mango, papaya, tomato, cabbage, onion,) in the Western coast and adjacent areas of the lakewetland, according an expert (age 54) in Natural Resource Management and own field observation.

The high annual rate of expansion of settlement (by $6.4 \%$ or 693.9 ha) in 1990 - 2019 was a consequence of various factors such as rural to rural migration (in-migration) to the plain Western coasts of the wetland, natural increase-induced expansion of rural villages, and development and expansion of infrastructures (Arba-Minch University, Arba-Minch Airport Terminal, modern irrigation structures, concrete and asphalted roads, and the Arba-Minch Crocodile Ranch) surrounding the lake-wetland. Expansion of urban centers like Birbir (MirabAbaya) town and Arba-Minch city was also a vital cause for the high rate of settlement expansion in the study site, which was underlain by natural increase and rural to urban migration-led rapid population growth. Studies also revealed that the degradation of forest, woodland and shrubland covers in the Western coast of the Abaya- 
Chamo depression was caused by fast population growth-led expansion of settlement and agriculture, which was rooted by high magnitude of in-migration from Gamo-highlands and Wolaiyta areas since the 1960s (Kebede, 2012; Assefa and Bork, 2016; Gelaw, 2019). Lake Abaya-Chamo wetland ecosystems are under considerable stress due to unsustainable rates of resource exploitation, inadequate and inappropriate management regimes, degradation of lake catchments and high demand for water, fish and agriculture products.
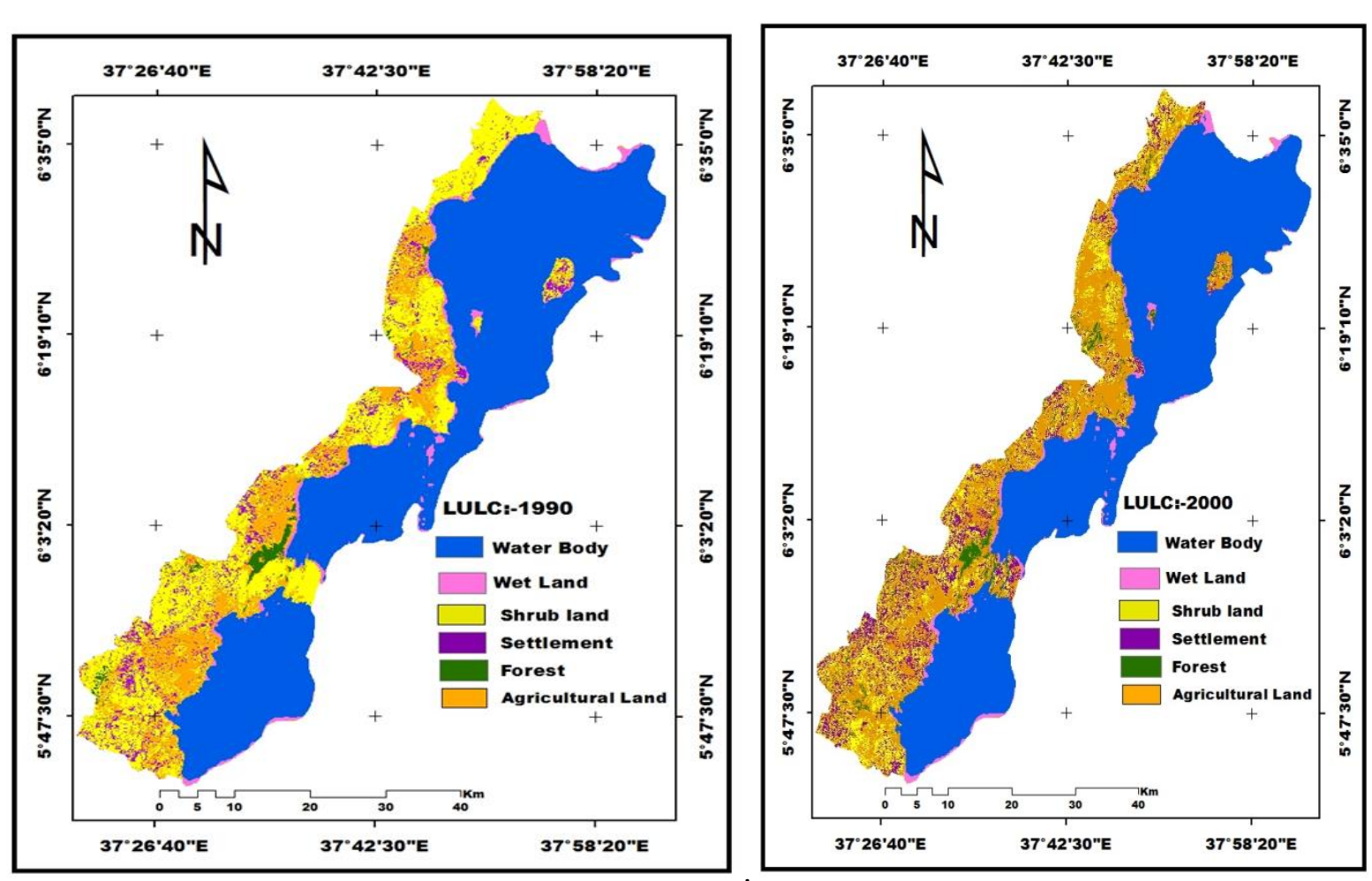

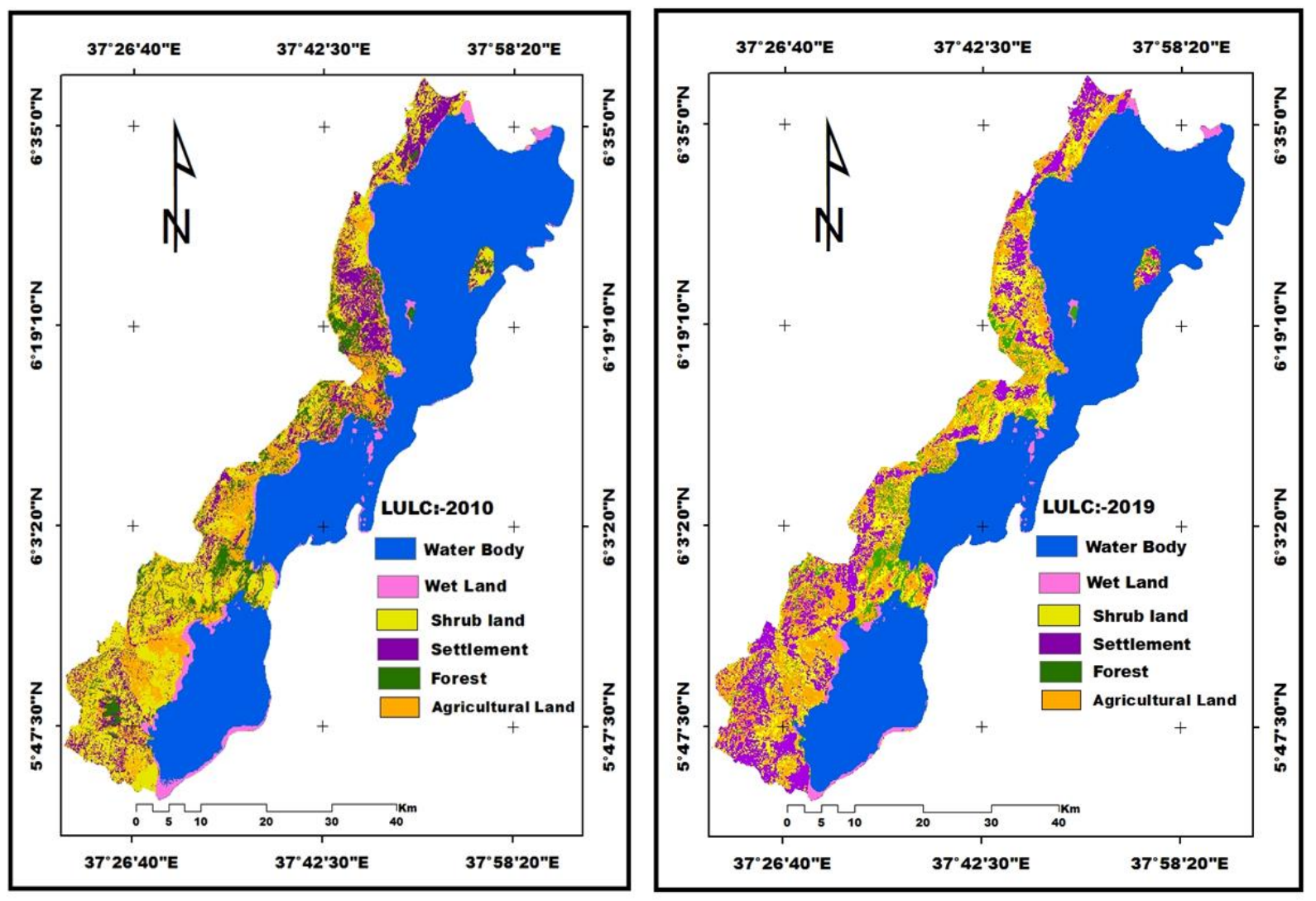

Figure 4. LULC of Lake Abaya-Chamo Wetland in 1990, 2000, 2010 and 2019 (Source: Own Design via ArcGIS, 2021)

'Swamp' area of the lake-wetland, like shrubland cover, has been decreasing at progressively increasing magnitudes of changes in the four decades' period (1990 - 2019); that is, where the magnitude of decline of the swamp cover was smaller (11.4\% or 700 ha) in the initial period (1990 -2000), moderate (16\% or 867 ha) in $2000-2010$ and the largest ( $31.3 \%$ or 1,424 ha) in the latest period $(2010-2019)$ accounted in by the study (Table 3). This is mainly a result of the progressively increasing sediment load into Abaya and Chamo lakes (Schütt et al., 2002). Meaning, land degradation in the Western Escarpment of the Southern Rift-Valley of Ethiopia [due to exploitation of fuel-wood and construction materials, overgrazing, over-browsing, and conversion of forest and woodland to cropland and settlement (Kebede, 2012; Assefa and Bork, 2016; Gelaw, 2019)] has resulted in increasing siltation in the floors of Abaya and Chamo lakes; the increasing siltation, in turn, led to the decline depth of the lakes (Schütt et al., 2002), and the displacement and lateral expansion of the lakes' water, and the subsequent shrinkage of the 'swamp' area of the lake-wetland by $48.9 \%(2,991$ ha) within 1990 - 2019 (Table 3). That is, the progressively increasing siltation-led expansion of 'water' body was the main cause of decline of the 'swamp' area of Abaya-Chamo lake-wetland; this is so because, the progressively increasing magnitude of increasing trend of 'water' body had been accompanied by progressively increasing magnitude of decline trend of 'swamp' area in the three decades' period as these LULC classes are configurated inherently adjacent to each other (Table 3 and Figure 4). Analysis results of the NDVI and NDWI also confirm 
the contradicting trends of 'wet/swamp' area and 'water' cover of the lake-wetland (Table 5 and Figure 3). Anyway, siltation problem of Abaya and Chamo lakes is the main cause of swamp area loss, a consequence of LULC dynamics and a vital degradation indicator of the lake-wetland.

Population increase-led expansion of settlement (infrastructures), agroforestry practice and drought might have been the other driving forces of the decline of 'swamp' area, especially, in 1990 - 2000 since the magnitude of decline of 'swamp' area had exceeded the magnitude of expansion of 'water' body by 101 ha in the same period (Table 3). Overgrazing and intensive livestock grazing induced compaction of the spongy soil/land might also have a slight contribution to the shrinkage of the 'swamp' area of Lake Abaya-Chamo wetland.

\section{Conclusion}

Lake Abaya-Chamo wetland is getting threatened overtime due to largely anthropogenic factors-induced LULC dynamics in the period 1990 - 2019. Settlement, agriculture, water body and forest cover of the lake-wetland showed net increases in three decades. Whereas, shrubland and 'swamp' area experienced significant net decline (by almost half of each) in 30 years. While settlement and water body increased at progressively increasing magnitudes of changes in three decades, shrubland and swamp cover declined at progressively increasing magnitudes of loss in the same periods. Increasing agroforestry practice by smallholder farmers and small-scale investors overtime contributed to the net increase in forest cover, and for the huge magnitude of shrinkage of shrubland (by $48.9 \%$ ) in lake Abaya-Chamo wetland. Decline of shrubland and natural forest was also driven by settlement and farm expansion. Generally, the LULC dynamics led to depletion of natural forest and shrubland in the coasts and uplands of the lake-basin, increasing runoff erosion and sediment load into plus pollution of the lake-wetland, invasion of the lakes by a strange plant water hyacinth('emboch'), siltation-led displacement of the lakes' water, area shrinkage and loss of biodiversity of the swamp, and to the overall degradation of lake Abaya-Chamo -wetland and its ecological services in the Southern Rift-Valley of Ethiopia.

To curb the impact of LULC dynamics on wetlands, the government should: (i) formulate clear policy, institutional and legal framework on the management of wetlands; (ii) revise the investment policy and enforcement of impact assessment; (iii) enforce 'user tax' (on users of land, water) and/or 'pollution charge' (on polluters of land, water) on investors in agriculture and other sectors in risky areas, adjacent to wetlands; (iv) reforest and afforest the uplands surrounding wetlands; and (v) revise the policy on the allocation of land uses.

\section{Availability of data and materials}

All data generated or analyzed during this study are included within the article

\section{Competing interests}


The authors declare that they have no competing interests.

\section{References:}

Alemayehu, T., Ayenew, T., and Kebede, S., (2006). Hydrogeochemical and Lake Level Changes in the Ethiopian Rift. Journal, 316: 290 - 300

Assefa, E., and Bork, H.R., (2016). Dynamics and Driving Forces of Agricultural Landscapes in Southern Ethiopia: a Case Study of Chencha and Arba Minch Areas. Journal of Land Use Science, 11 (3): 278 293, http://dx.doi.org/10.1080/1747423X.2014.940613

Baker C., Lawrence R.L., Montagne C., and Patten D., (2007). Detection of Wetland Ecosystem Using Landsat Imagery and Change Vector Analysis. Wetlands, 27 (3): 610 - 619

Ballanti L., Byrd K.B., Woo I., Ellings C., (2017). Remote Sensing for Wetland Mapping and Historical Change Detection at Nisqually River Delta. Sustainability, 9 (1919): 1 - 32. www.mdpi.com/journal/sustainability

Bekele, S., (2001). Investigation of Water Resources Aimed at Multi-purpose Development with Limited Data Situation: The Case of Abaya-Chamo Basin, Ethiopia. Ph.D. Thesis, Dresden: Dresden University of Technology, Germany

CBD (Convention on Biological Diversity) (2015). Wetlands and Ecosystem Services: CBD Press Brief. World Wetlands Day. Gland: Ramsar Convention on Wetlands and Secretariat of CBD, Switzerland. www.cbd.int

Clarkson, B.R, Gerbeaux, P.J.R., and Ausseil, A.E, (2014). Wetland Ecosystem Services. ResearchGate, 1 (14): 191 - 202 https://www.researchgate.net/publication/260436894

Creswell, J.W (2009). Research Design: Quantitative, Qualitative and Mixed Method Approaches. Third Edition, Los Angles: the SAGE Publications Ltd., USA

CSA (Central Statistical Authority) (2016). Arba-Minch Zuria (Woreda) Demographic Survey Surveillance and Aids Mortality Surveillance. Baseline Report. Addis Ababa: CSA, Ethiopia

Davidson, N. C. (2014). How Much Wetland Has the World Lost? Long-term and Recent Trends in Global Wetland Area. Marine and Freshwater Research, 65: 934 - 941

Dise, N.B. (2009). Peatland Response to Global Change. Science, 326: 810 - 811

Dubeau, P., (2016). Mapping and Characterizing Wetlands and Wetland Dynamics in the Highlands of Ethiopia Using Random Forest Classification. MSc Thesis Report. Ottawa: Carleton University, Ontario (Canada)

Elias E, Seifu W, Tesfaye B., and Girmay W., (2019). Impact of Land Use/Cover Changes on Lake Ecosystem of Ethiopia Central Rift Valley. Cogent Food and Agriculture, 5 (1): 1 - 19

Edwards, T. C., Moisen, G. G., \& Cutler, D. R. (1998). Assessing map accuracy in a remotely sensed, ecoregion-scale cover map. Remote Sensing of Environment, 63, 73- 83. 
Erwin, K.L. (2009). Wetlands and Global Climate Change: The Role of Wetland Restoration in a Changing World. Wetland Ecol. Management, 17(1): 71 - 84

Feoli, E and Zerihun, W. (2000). Fuzzy Set Analysis of the Ethiopian Rift Valley Vegetation in Relation to Anthropogenic Influences. Plant ecology, 147: 219 - 225

Galatowitsch, SM (2018). Natural and Anthropogenic Drivers of Wetland Changes. In: Finlayson, C.M., Milton G.R., Prentice R.C., and Davidson, N.C. (eds). The Wetland Book (Pp. 359 - 367), Springer Nature, Switzerland http://www.link.springer.com

Gelaw, A., (2007). Land Use Change and GIS-Based Land Suitability Analysis in Southern Rift Valley of Ethiopia: The Case of Lante Alluvial Fan. M.A Thesis, Addis Ababa: Addis Ababa University, Ethiopia

Gelaw, A., (2019). Analysis of the Values and Impacts of Ecosystem Services Dynamics, and Valuation of Selected Provisioning Services in Hare River Catchment, Southern Ethiopia. A PhD Dissertation, Addis Ababa: Addis Ababa University, Ethiopia

Giweta M., and Worku Y., (2018). Reversing the Degradation of Ethiopian Wetlands: Is It Unachievable Phrase or a Call to Effective Action? International Jour of Env't Sciences and Natural Sciences, 14 (5): 136 146

Govender, M., Chetty, K., Bulcock, H., 2007. A review of hyperspectral remote sensing and its application in vegetation and water resource studies. Water Sa 33 (2).

Hussien, K.A (2014). Assessment of Spatiotemporal Changes of Wetlands Using GIS and RS Techniques in Dawa Chefa Area in the Northern Central Ethiopian Highlands. MSc Thesis Report, Mekelle: Mekelle University, Ethiopia.

Jensen, J.R. Introductory Digital Image Processing (1996). A Remote Sensing Perspective, 2nd ed.; Prentice Hall:Saddle River, NJ, USA,; ISBN 978-0131453616.

Kebede, Y., (2012). Land Use/Cover Dynamics, Environmental Degradation and Management Practices in Hare River Catchment, Abaya-Chamo Basin, Ethiopia, Using Geo-Spatial Technology; A Ph.D Thesis, Andhra: Department of Env'tal Sciences (Andhra University), India

Klemas, V. (2011). Remote Sensing of Wetlands: Case Studies Comparing Practical Techniques. J. Coastal Research, 27: $418-427$

Lambin, E.F., Geist, H.J., and Erika, L., (2003). Dynamics of Land Use and Land Cover Change in Tropical Regions; Annu. Rev. Environ. Resour., 28: 205 - 214

Legesse T. (2007). Dynamics of Wetland Ecosystems: A Study on Hydrologic Dynamics of the Wetlands of IluAbba Bora Highlands, Southwest Ethiopia. Master Thesis, Brussels: University of Brussels, Switzerland

Lillesand MT, Kiefer WR, and Dupman WJ. (2004). Remote Sensing and Image Interpretation. $5^{\text {th }}$ Edition. John Wiley and Sons Inc., New York, USA 
Manonmani, R. and Suganya, G.M.D (2010). Remote Sensing and GIS Application in Change Detection Study in Urban Zone Using Multitemporal Satellite. Int. J. Geomat. Geosci., 1: 60 - 65

McFeeters, S.K. (1996). The Use of Normalized Difference Water Index in the Delineation of Open Water Features. Int. J. Remote Sens., 17, 1425 - 1432

MEA (Millennium Ecosystem Assessment) (2005). Ecosystems and Human Well-being: Wetlands and Water Synthesis. Washington, DC: World Resources Institute, USA. Website: http://www.maweb.org

Morris J.T., Sundareshwar P.V., Nietch C.T., Kjerfve B., Cahoon D.R. (2002). Responses of Coastal Wetlands to Rising Sea Level. Ecology, 83: 2869 - 2877

NMA (National Meteorological Agency) (2019). Climate (Temperature and Rainfall) Data Records within 1982 - 2018. A Report by the Meteorological Station at Arba Minch University (Abaya-Chamo Basin). Addis Ababa: the NMA (Ethiopia)

Parry, M.L.; Canziani, O.F.; Palutikof, J.P.; van der Linden, P.J.; Hanson, C. (2007). Climate Change: Impacts, Adaptation and Vulnerability. Contribution of Working Group II to the Fourth Assessment Report of the IPCC. Cambridge: Cambridge University Press: UK

RCS (Ramsar Convention Secretariat) (2016). An Introduction to the Convention on Wetlands. Fifth Edition. Gland: RCS, Switzerland

Simane B, Benjamin FZ, and Mutlu O (2013). Agroecosystem Analysis of the Choke Mountain Watersheds, Ethiopia. Sustainability 5 (2): $592-616$

Schütt B., Förch G., Bekele S., and Thiemann S., (2002). Modern Water Level and Sediment Accumulation Changes of Lake Abaya, Southern Ethiopia: A Case Study from the Northern Lake Area. Research Report, Dresden: Dresden University of Technology, Germany

Schuyt, K.D. (2005). Economic Consequences of Wetland Degradation for Local Population in Africa. Ecol. Econ. 53: $177-190$

TEEB (The Economics of Ecosystems and Biodiversity) (2013). The Economics of Ecosystems and Biodiversity for Water and Wetlands. London and Brussels: Institute for European Environmental Policy (IEEP)

Teffera F.E, Lemmens P, Deriemaecker A, Brendonck L., Dondeyne S, Deckers J, Bauer, H. Gamo, F.W, De Meester, L.A (2017). Call to Action: Strong Long-term Limnological Changes in the Two Largest Ethiopian Rift Valley Lakes, Abaya-Chamo. Inland Waters, 7, 129 - 137

Teklu, G., and Kassahun, M., (2017). Threats and Opportunities to Major Rift Valley Lakes Wetlands of Ethiopia. Agri Res \& Tech Open Access J, 9 (1): 555 - 571

Tenalem, A., (2009). Natural Lakes of Ethiopia. Research Report. Addis Ababa: Addis Ababa University Press, Ethiopia

Unbushe D.G (2013). Wetland Vegetation Composition and Ecology of Abaya and Chamo in Southern and Fincha-Chomen and Dabus in Western Ethiopia. A PhD. Thesis, Addis Ababa University, Addis Ababa 
Uncha, A., (2014). Indigenous Soil Management Techniques and the Impact of Modern Agricultural Technologies in Gamo Highlands, Southern Ethiopia. Ph. D Dissertation, Pretoria: University of South Africa

UNEP (United Nations Environment Program) (2012). Global Environmental Outlook. Environment for the Future We Want. Nairobi: UNEP, Kenya

Wolde-Yohannes, A., Cotter, M., Kelboro, G., and Dessalegn, W. (2018). Land Use and Land Cover Changes and their Effects on the Landscape of Abaya-Chamo Basin, Southern Ethiopia. Land, 7(1): 22 - 33

Wondie, A (2018). Ecological Conditions and Ecosystem Services of Wetlands in the Lake Tana Area, Ethiopia. Ecohydrology and Hydrobiology, 18 (2): 231 - 244

Wood A, and Dixon A (2002). Sustainable Wetland Management in Illubabor Zone: Research Report Summary. Huddersfield: The University of Huddersfield, UK

Zedler, J.B. and Kercher, S. (2005). Wetland Resources: Status, Trends, Ecosystem Services and Restorability. Annual Review of Environment and Resources, 30: 39 - 74

Zinabu G., (2002). The Ethiopian Rift Valley Lakes: Major Threats and Strategies for Conservation; In: Tudorancea, C. and Taylor, W.D., (eds), Ethiopian Rift Valley Lakes, pp. 259 - 271, Leiden: Backhuys Publishers, Netherlands

\section{Acknowledgements:}

The authors wish to thank assistants of data collection for this study. We would also like to thank the reviewers of this article for their critical observations and everyone who contributed to the improvement of the paper. Finally, we gratefully acknowledge the financial support of the Arba Minch University.

\section{Funding}

The first author acknowledges Arba Minch University for financial support of this study.

\section{Author information}

Affiliations

Tariku Zekarias: Department of Geography and Environmental Studies, Arba Minch University, PO Box 21, Arba Minch, Ethiopia, phone : +251-913682300; Email: tarezekarias@ gmail.com

Vanum Govindu: Department of Geography and Environmental Studies, Arba Minch University, PO Box.21,Arba Minch,Ethiopia, phone: +251-985414821, gisgovindu@gmail.com 
Yechale Kebede: Department of Geography and Environmental Studies, Arba Minch University, PO Box 21, Arba Minch, Ethiopia, phone: +251911390405 E-mail: kebyechenvi@gmail.com

Abren Gelaw: Department of Geography and Environmental Studies, Arba Minch University, P.O.Box 21, Arba Minch, Ethiopia, phone +251913623251 E-mail abren mekon@yahoo.com

\section{Contributions}

TZ has made a substantial contribution to the conception and designing of the study, data collection, data analysis, interpretation of the results, and prepared the manuscript. VG, YK and AG have contributed to planning the study, supervising the study, editing, commenting, and suggesting ideas in the manuscript preparation process. Finally, all authors read and approved the final manuscript for publication.

\section{Corresponding author:}

Correspondence to Mr. Tariku Zekarias.

\section{Ethics Declarations}

\section{Ethics approval and consent to participate}

An effort was made to conduct the research in an ethical manner. A research area permission letter was obtained from the concerned institutions and the participants' consent was asked before commencing the interviews, discussions and taking photographs.

\section{Additional information}

\section{Publisher's Note}

Springer Nature remains neutral with regard to jurisdictional claims in published maps and institutional affiliations. 
Figures

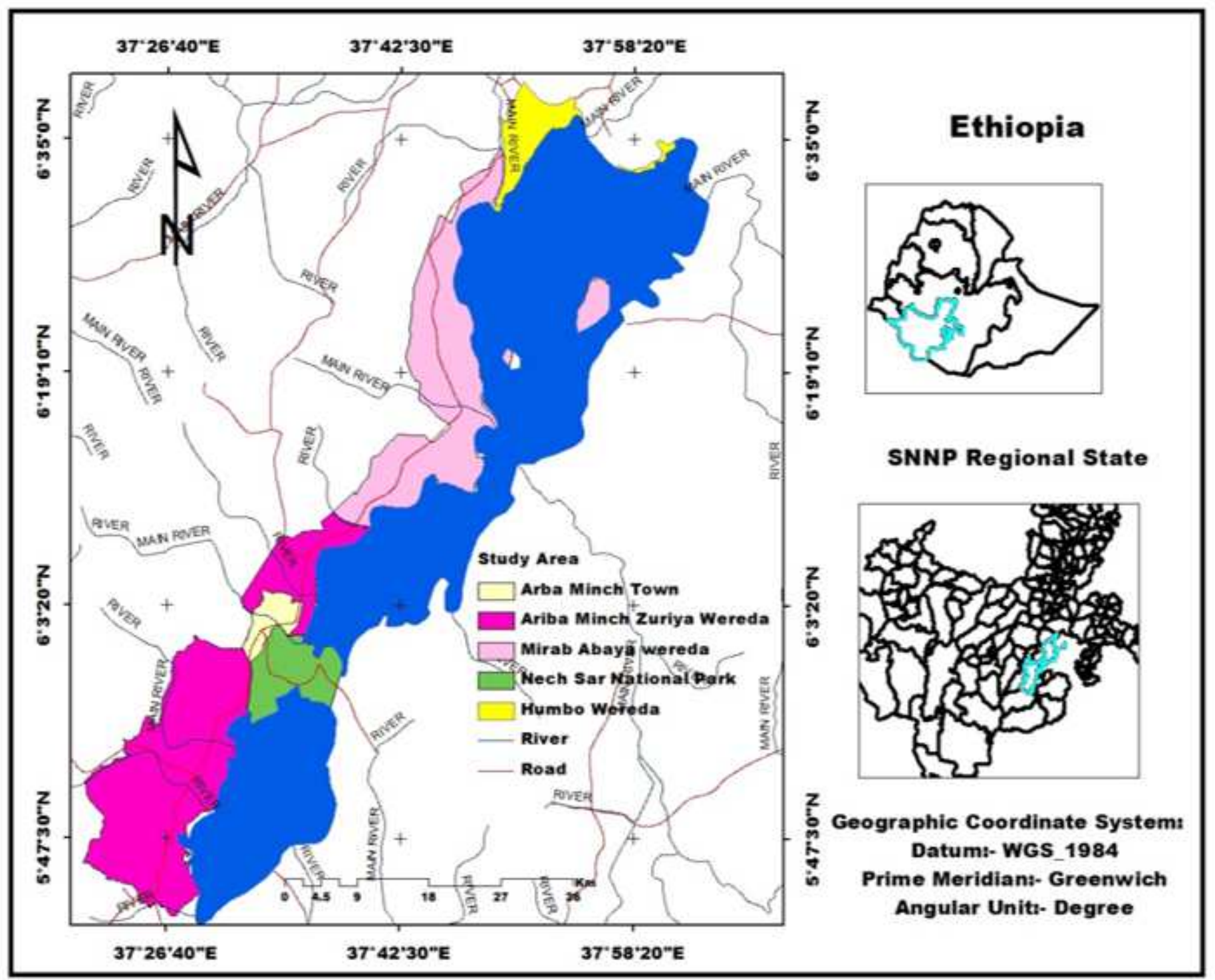

Figure 1

Lake Abaya-Chamo Wetland and Its Surrounding Areas (Source: Own Design via ArcGIS, 2021) Note: The designations employed and the presentation of the material on this map do not imply the expression of any opinion whatsoever on the part of Research Square concerning the legal status of any country, territory, city or area or of its authorities, or concerning the delimitation of its frontiers or boundaries. This map has been provided by the authors. 


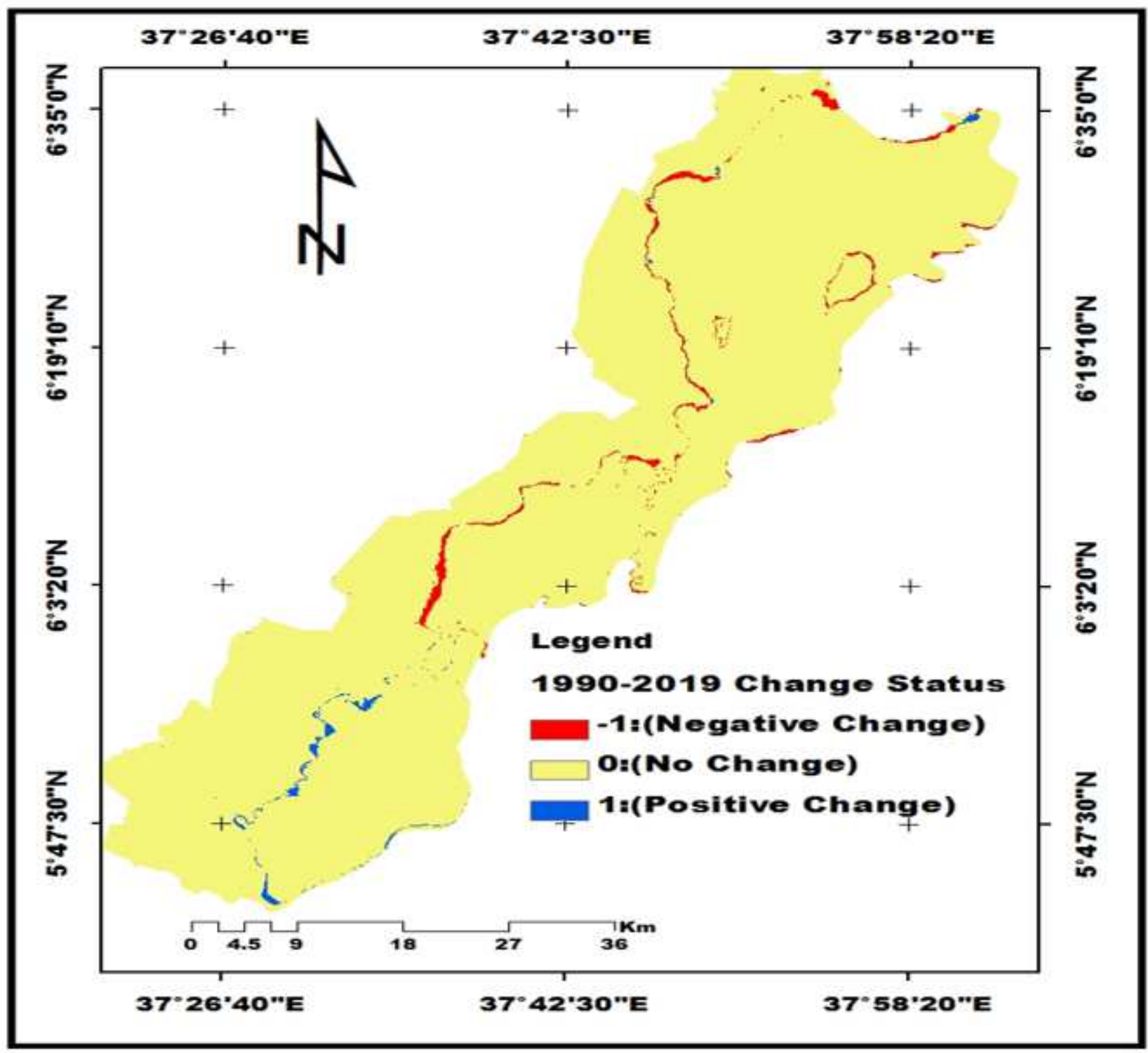

Figure 2

Map of the Dynamics of the Lake-Wetland in 1990 - 2019 (Source: Own Analysis via ArcGIS, 2021) Note: The designations employed and the presentation of the material on this map do not imply the expression of any opinion whatsoever on the part of Research Square concerning the legal status of any country, territory, city or area or of its authorities, or concerning the delimitation of its frontiers or boundaries. This map has been provided by the authors. 

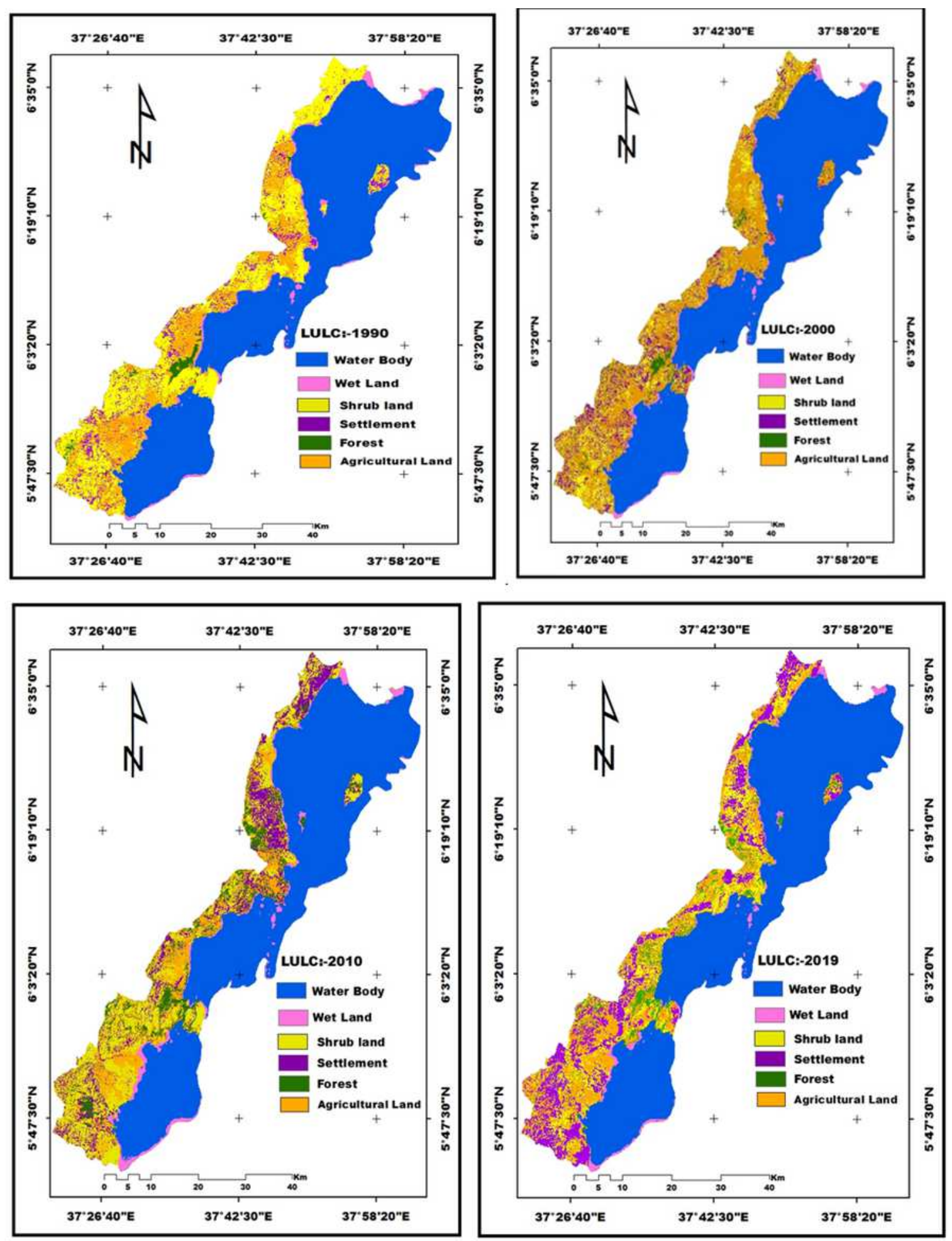

\section{Figure 3}

LULC of Lake Abaya-Chamo Wetland in 1990, 2000, 2010 and 2019 (Source: Own Design via ArcGIS, 2021) Note: The designations employed and the presentation of the material on this map do not imply the expression of any opinion whatsoever on the part of Research Square concerning the legal status of any country, territory, city or area or of its authorities, or concerning the delimitation of its frontiers or boundaries. This map has been provided by the authors. 